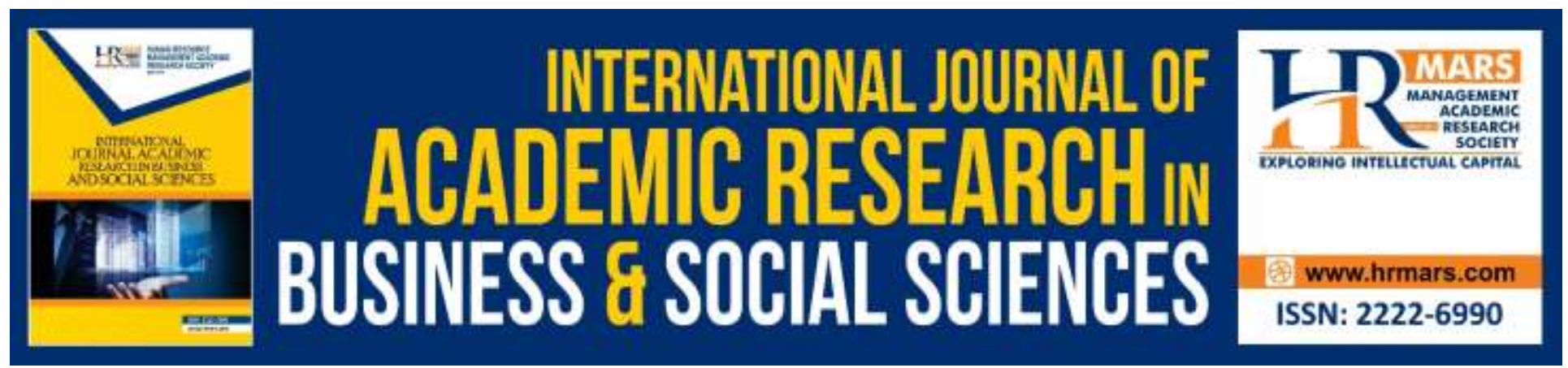

\title{
Exploring the Learning Theories Underpinning in Technical, Vocational, Education and Training (TVET) Curriculum Perceived by TVET Students
}

\author{
Aminuddin Hassan \& Lam Kim Wai
}

To Link this Article: http://dx.doi.org/10.6007/IJARBSS/v9-i11/6706

DOI: 10.6007/IJARBSS/v9-i11/6706

Received: 15 October 2019, Revised: 30 October 2019, Accepted: 13 November 2019

Published Online: 29 November 2019

In-Text Citation: (Hassan, \& Wai, 2019)

To Cite this Article: Hassan, A., \& Wai, L. K. (2019). Exploring the Learning Theories Underpinning in Technical, Vocational, Education and Training (TVET) Curriculum Perceived by TVET Students. International Journal of Academic Research in Business and Social Sciences, 9(11), 1372-1381.

Copyright: (C) 2019 The Author(s)

Published by Human Resource Management Academic Research Society (www.hrmars.com)

This article is published under the Creative Commons Attribution (CC BY 4.0) license. Anyone may reproduce, distribute, translate and create derivative works of this article (for both commercial and non-commercial purposes), subject to full attribution to the original publication and authors. The full terms of this license may be seen at: http://creativecommons.org/licences/by/4.0/legalcode

Vol. 9, No. 11, 2019, Pg. 1372 - 1381

Full Terms \& Conditions of access and use can be found at http://hrmars.com/index.php/pages/detail/publication-ethics 


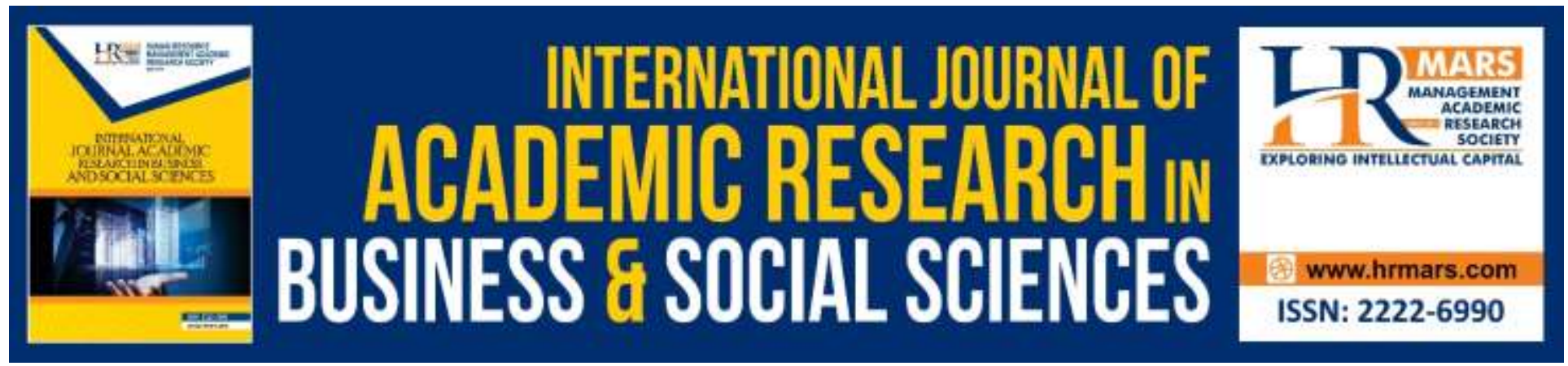

\title{
Exploring the Learning Theories Underpinning in Technical, Vocational, Education and Training (TVET) Curriculum Perceived by TVET Students
}

\author{
Aminuddin Hassan \& Lam Kim Wai \\ Faculty of Educational Studies, University Putra Malaysia (UPM), Serdang, Selangor, Malaysia
}

\begin{abstract}
The purpose of the study was to investigate students' perceptions of level of knowledge about learning theories in the Technical and Vocational Education and Training (TVET) course possessed in one vocational college in Kuala Lumpur and one public institution in Selangor. Data were gathered from a sample of 69 and 171 TVET students using the paper-and-pencil Instruction Competency Questionnaire (ICQ) instrument. Percentage and frequency distributions were employed to analysis the data. Data were collected using a questionnaire administered to 171 randomly sampled TVET Students in Malaysia. Of those surveyed, 171 returned useable responses. Descriptive statistic was conducted to analyse the data. Of the respondents, $71.3 \%$ indicated that they have moderate low to low level of knowledge on behavioural, cognitive, and constructivist learning theories. The study also reported a need for students to increase their knowledge, especially, on constructivist learning theory, to empower them for taking charge of their own experiential learning to enhance their 21st century skills.

Keywords: Technical and Vocational Education and Training (TVET) Curriculum, Perception, Learning Theory, Behavioural Learning Theory, Cognitive Learning Theory, Constructivist Learning Theory.
\end{abstract}

\section{Introduction}

In exploring the latest and relevant learning theories in integrating Technical Education, Vocational, Education and Training as the basis for technical and vocational education, Malaysian students in this field are the perfect group to give their views and perceptions on this.

They will evaluate and demonstrate on whether they have a high or a low level of knowledge on behavioural, cognitive, and constructivist learning theories that are often linked to the process of knowledge building and applying any education practices. In fact, it is also necessary for 
INTERNATIONAL JOURNAL OF ACADEMIC RESEARCH IN BUSINESS AND SOCIAL SCIENCES

Vol. 9, No. 11, November, 2019, E-ISSN: 2222-6990 @ 2019 HRMARS

university students who study in this area to increase their knowledge, especially on constructivist learning theory, to empower them to conduct their own teaching and learning in order to improve their 21st century skills.

\section{Purpose of the Study}

The purpose of this study is to determine TVET student's perceptions of importance and level of knowledge of instruction competencies in reasoning skills and perceived needs for instruction knowledge in TVET curriculum.

\section{Statement of Research Problem}

There are little researches that studied learning theories integrated in the TVET curriculum among secondary schools and university students, especially in Malaysia context. Hence, more studies require to be carried out to examine the perception of importance and level of knowledge of learning theory integrated in technical curriculum among secondary school students and university students in Malaysia, thus, the level of self-perception of the importance and knowledge of learning theories among students has remained vague, therefore this study was conducted to fulfil this purpose.

\section{Literature Review}

\section{Learning Theory}

Based on previous literatures, the major three main learning theories were, behaviourism, cognitivism, and constructivism. These theories are discussed in relation to how they can be applied to TVET curriculum to allow students to understand learning objectives.

\section{Behaviourist Learning Theory}

Behaviourist learning theory emphasized the role of the environment in determining behaviour (Rabinowitz, 2004), whereby, an event or activities in the environment will cause something to happen in the mind, which then causes some behaviour to occur (Rabinowitz, 2004; Flanagan, 1991). Hence, the instructional designer will use this theory by paying attention to the setting of the environment where events or activities take place, and possible to manipulate the consequences of different behavioural responses (Rabinowitz, 2004) or teachers would present lesson objectives with some hints or cues in a linear fashion to lead students to a specific behaviour, and use effect to reinforce the specific behaviour.

In addition, behaviourism provides some concepts or assumptions for assessment purpose. For example, the engineering syllabuses normally integrate theories with other useful applications, such as, behaviour shaping and behaviour modification and task analysis (Hassan, 2011; Juhmani, 2018).

Peel's (2005) conducted a study to examine the impact of behaviourism on creating coaching practice or integrated technique, that allow specific 'goal objectives' and 'reinforcement' process 
to be adopted to response on the practice issues, to strengthen the adoption of good coaching practice. The study also highlighted the needs to recognise the effect of coaching feedback and performance improvement. However, this article only focuses on coaching community, lack of explanation on the approaches or strategies to assess and evaluate the 'goal setting' or 'goal objectives' against performance, as well as, failure to measure the relationship between coaching feedback and associated improvement in performance, and failure to establish this relationship is cause in part by our learning theories, or more specifically, behaviourism, together with its basic assumptions that a stimulus will cause a response.

A study by Pearson et al. (2002) explained that, the behavioural reinforcement/incentives approach and behavioural learning techniques used in the interventions / treatments programs, including related social skills development programs, such as, reasoning and rehabilitation programs conducted in laboratory studies to control subhuman and human behaviour patterns, have effectively reduced recidivism rates for offenders in prison, jail, probation, or parole settings using experimental methods. However, this article only focuses on drug abuse settings and measure the behavioural reinforcement/incentives approach or techniques using experimentation method, without explaining the internal instructional processes involved in developing the interventions / treatments programs.

\section{Cognitive Learning Theory}

Cognitive theory will assist learner to obtain the thinking techniques in order to improve performance in job (Sink, 2014), because the learning occurs was based on how information is encoding, storage, and retrieval in the human memory (Foshay, Silber, \& Stelnicki, 2003) and frequently follow Gagné's nine events of instruction. For example, findings from Hua's (2016) study reported a good level of program quality and achieved good performance on instruction, interactivity, and technique aspects that allow share approach to integrate information literacy within academic programmes, results in, a more effective techniques to curriculum design based on the ADDIE model. However, this study was lack of cognitive load measurement techniques if it is to continue to use as a framework for instructional design. In addition, the study also lack explanation about the constructs itself, results in problems with validity and reliability issue, hence, it may not useful when tested in classrooms or real-world scenarios.

In another study by Moradmand, Datta, and Oakley (2014) to discuss the process of applying ADDIE instructional design model along with all the elements of Bloom/Anderson taxonomy (2001) of cognitive learning theory, to frame and explain materials for helping primary school teachers' in their teaching and learning of mathematics in classroom, indicated that, teachers demonstrated the ability to explain pedagogical and learning objectives that are according to requirement by Australian Curriculum, after using the ADDIE instructional design model as a guide to the process of designing, implementing and evaluating the My Maths Story project's interactive multimedia mathematics software. The study also reported that the mathematics multimedia software enhances students learning of the subject content either individually or in 
pairs or small groups. However, this study lack of the ability to show the link between theory for educational mathematics multimedia software and application of technology using experiment method to measure thought processes in term of, how teachers and students attend to, manage and remember information during learning process.

\section{Constructivist Learning Theory}

Constructivism is a learning theory that concerned with the experiences and contexts that make the learners willing and enable to learn (McGriff, 2001). Constructivist learning design focuses on activity that allow create and recreate past experience of students and the modification to new learning. Students are core matter while teachers just act as facilitators (Botto, Schorr, \& Lema 2006).

A study by Zainuddin and Sahrir (2015) investigated the validity of constructivism, second language acquisition and multimedia learning theories and design principles (modified ADDIE model of instructional design) for design and development of multimedia software in teaching and learning Arabic vocabulary for non-native Arab students at International Islamic University Malaysia (IIUM), Malaysia. Finding of the study showed that the production and development of an Arabic vocabulary multimedia courseware based on theories, design and development methods as discussed earlier had a valid impact on the learning and meet the contextual analysis of learners needs. However, no explanation on instructional design theories used to create the courseware were provided. In addition, the study also did not report the procedures involved in validating the results generated by the study.

In another study by Bajbouj, Alwi, and Shah (2015) to determine learning theories and instructional design involved in the theoretical framework in the creation of online courses for elearning PL sites. Findings showed that difficulty level and ease of use had effect on the study, however, the presentation methods are applicable to selected field. The study also concluded that the instructional design model caused the PL online courses became more effective, whereby, learners were motivated to learn the courses in all levels. However, the study employed a mixed methodology research design in e-learning environment with novice programmers and focuses on developing new instructional design model based on constructivist perspective that will be closed to the mathematical concepts.

\section{Methodology}

This research applied the survey design and used the quantitative approach based on questionnaire. 


\section{Research Design}

\section{Participants and Data Collection}

The respondents for this study was the students who were enrolled in TVET courses at one vocational college in Kuala Lumpur and one public university in Selangor and stratified sampling method was adopted for this study (Creswell, 2012).

\section{Sample Descriptions}

One hundred and seventy-one students studying TVET courses participated in this research. A Likert scale questionnaire (1- None; 2-Very Little; 3- Somewhat; 4- Very; and 5- A Great Deal) was used to gather responses from the students. Students in the study were asked to complete the Instruction Technology Competency Scale to adequately address their perceptions about learning theories learned in their curriculum.

Stratified random sampling technique was used for vocational college and public university, whereby, a sample of 69 and 217 were given questionnaires by the person-in-charge of the college and department respectively. 46 and 171 questionnaires were returned giving a response rate of $68.9 \%$ and $78.8 \%$ respectively.

The collected data was analysed using SPSS. Researcher hand delivered the hardcopy of the instrument to person-in-charge of vocational programmes in one vocational college in Kuala Lumpur and selected student representatives from year 1, 2 and 3 cohorts from public university as suggested by person-in charge and department of technical education. 46 and 125 usable questionnaires were returned by students from vocational college and public university, representing a $100 \%$ and $73.1 \%$ response rate.

\section{Findings and Discussion \\ Demographics}

The demographic data was analysed using means, variances, percentage and frequency distributions for variables, namely, age, gender, school name, training on designing instruction, experience in designing instruction, and vocational education program that were significance for this study.

Questionnaires were supplied to selected students in the school and department based on years of study. 69 were returned giving a response rate of 73\%. Every department in the school was represented by the respondents, 31 of whom were male and 38 females.

\section{Results}

Quantitative data were screened for entry errors and reported by frequency distributions, means, and standard deviations. 


\section{Questionnaire Survey at Institution A and Institution B}

Questionnaire was hand delivered to selected students in the one public university in Selangor and the person-in-charge of one vocational college in Kuala Lumpur. 125 and 46 responses were returned giving a response rate of $100 \%$. Each program in both institutions were represented by the respondents, which 69 of whom were male and 102 females. The following results displays are organised into two groups, vocational college students' and public university students' responses to questions about their perception of applying and mastery of learning theories in their curriculum (see table 1 below). The results are shown in percentages of the total number of answers ( $n$ ) according to the question being asked.

Table 1. Demographic profile of respondents.

\begin{tabular}{lllll}
\hline Demographic Profile & \multicolumn{2}{l}{ Institution A } & \multicolumn{2}{l}{ Institution B } \\
\cline { 2 - 5 } & Frequency & $\begin{array}{l}\text { Percentage } \\
\text { (\%) }\end{array}$ & Frequency & $\begin{array}{l}\text { Percentage } \\
\text { (\%) }\end{array}$ \\
\hline $\mathrm{N}$ & 125 & & 46 & \\
\hline Age & & & & \\
\hline $16-17$ & 0 & $0 \%$ & 3 & $7 \%$ \\
\hline $18-19$ & 0 & $0 \%$ & 40 & $86 \%$ \\
\hline $20-21$ & 70 & $56 \%$ & 3 & $7 \%$ \\
\hline $22-23$ & 28 & $22 \%$ & 0 & $0 \%$ \\
\hline $24-25$ & 19 & $15 \%$ & 0 & $0 \%$ \\
\hline Above 25 & 8 & $6 \%$ & 0 & $0 \%$ \\
\hline Gender & & & & \\
\hline Male & & & & $87 \%$ \\
\hline Female & 29 & $23 \%$ & 40 & $13 \%$ \\
\hline
\end{tabular}

The figure below shows the results of the answers provided by institution $A$ and institution $B$ in the survey to the question: "determine the learning theories as perceived by TVET students?"

\begin{tabular}{lllll}
\hline Types of learning theory & & & & \\
\hline Behaviourist & 45 & $36 \%$ & 6 & $13 \%$ \\
\hline Cognitive & 35 & $28 \%$ & 23 & $50 \%$ \\
\hline Constructivist & 5 & $4 \%$ & 8 & $17 \%$ \\
\hline Behaviourist \& Cognitive & 6 & $4.8 \%$ & 0 & $0 \%$ \\
\hline Behaviourist \& Constructivist & 1 & $0.8 \%$ & 0 & $0 \%$ \\
\hline Cognitive \& Constructivist & 1 & $0.8 \%$ & 0 & $0 \%$ \\
\hline $\begin{array}{l}\text { Behaviourist \& Cognitive \& } \\
\text { Constructivist }\end{array}$ & 12 & $9.6 \%$ & 0 & $0 \%$ \\
\hline $\begin{array}{l}\text { Do Not Know } \\
\text { S }\end{array}$ & 20 & $16 . \%$ & 9 & $20 \%$
\end{tabular}


A basic demographic description of the participant' are female $77 \%$ and $23 \%$ of them are males. $82.5 \%$ of the participant's ages ranges between $18-23$, while $16.1 \%$ of them are between $24-$ over 25 and $1.8 \%$ are between the ages of $16-19$. The findings showed that $33.9 \%$ of the students indicated that they do have knowledge on Behavioural learning theory. $29.8 \%$ have knowledge on cognitive learning theory. $17 \%$ do not have any knowledge on learning theory. $7.6 \%$ and $7.0 \%$ of the students do have knowledge on Constructivist learning theory and both Behavioural learning theory \& Cognitive learning theory \& Constructivist learning theory. 3.5\% of the students do have knowledge on Behavioural learning theory \& Cognitive learning theory only.

\section{Summary and Discussion}

Students have moderate low to low level of knowledge on Behavioural learning theory, cognitive learning theory, and Constructivist learning theory. It suggests that student may lack of the ability to construct their own knowledge or meaning from the difference experiences they have learned in a lecture-type class. Therefore, there is a need to help students to acquire the competencies and knowledge by learning in ways that lead to understanding about the new information and, subsequently, constructing new knowledge based on their current knowledge. Unfortunately, the existing curriculum is not enough on its own. There is a need for new approaches to the development of curricula that support learning with understanding and encourage construction of new knowledge, where, students have the opportunities to see how their ideas can be transformed and formalized. This is important, because the outcome of instruction is to increase students' knowledge and capabilities of sophisticated levels of thinking and reasoning to support facilitate learning, which, in turn, to groom students with a real-world experience for their future employment in the 21st century.

\section{Implications of the Study}

The results of this study will add to the body of scholarly research and literature on TVET curriculum in Malaysia setting, with special focus on students' perceived importance and knowledge level of instruction competencies. In addition, the results also will provide government agency or department with the information, so that they can prepare specific professional development opportunities for addressing the perceived deficiency in student mastery of instruction knowledge.

\section{Limitations}

The limitations of this study are TVET student participation in the study is voluntary, and the time frame for the study was only six months. Furthermore, the study group is mainly students from one vocational college and one public universities in Kuala Lumpur and Selangor, therefore, the results may not apply to other institutions outside of the study group.

\section{Acknowledgement}

Authors express their gratitude to the Research Management Centre, University Putra Malaysia Ministry for supporting the research project under the UPM Putra Grant (Grant No. GP- 
INTERNATIONAL JOURNAL OF ACADEMIC RESEARCH IN BUSINESS AND SOCIAL SCIENCES

Vol. 9, No. 11, November, 2019, E-ISSN: 2222-6990 @ 2019 HRMARS

IPS/2016/9510600) and thank various Malaysian government agencies for granting approval to conduct the survey at vocational colleges.

\section{Corresponding Author}

Aminuddin Hassan Basri is associate professor at the Faculty of Educational Studies, Universiti Putra Malaysia, Selangor Darul Ehsan, Malaysia. Email: aminuddin@upm.edu.my

\section{References}

Adam, N. B. (2007). "Towards a Model for Knowledge Development in Virtual Environment: Strategies for Student Ownership." International Journal of Social Sciences 2 (2, 71-77.

Botto, T., Schorr, M., \& Lema, J. D. (2006). "Integrating web-based technology to assist and enhance instruction, assessment, and application of problem-based learning for manual therapy techniques used in athletic training and sport medicine." Systemic, Cybernetics and Informatics 4 (3), 43-46.

Flanagan, O. (1991). The science of the mind. Cambridge, MA: MIT Press.

Foshay, W. R., Silber, K. H., \& Stelnicki, M. (2003). Writing Training Materials That Work. San Francisco: Jossey-Bass/Pfeiffer.

Hassan, O. A. B. (2011). "Learning theories and assessment methodologies - An engineering educational perspective." European Journal of Engineering Education, 36 (4), 327-339.

Hua, Z. (2016). How to design and apply interactive digital educational TV programs based on the ADDIE model. International Journal of Information and Education Technology, 6(11), 884-889. doi: 10.7763/IJIET.2017.V6.810

Juhmani, O. I. (2018). The Effectiveness of Audit Committee on Curbing Earnings Management Practices - pre and post - BCGC 2011: Further Look, International Journal of Academic Research in Accounting, Finance and Management Sciences 8 (2): 250-258.

Lowenthal, P., and Muth, R. (2008). "Constructivism." In Encyclopaedia of the Social and Cultural Foundations of Education", edited by E. F. Provenzo, Jr., 1-5. Thousand Oaks, CA: Sage. http://www.patricklowenthal.com/publications/Constructivismpreprint.pdf

McGriff, S. J. (2001). Leadership in Higher Education: Instructional Designers in Faculty Development Programs In: Annual Proceedings of Selected Research and Development [and] Practice Papers Presented at the National Convention of the Association for Educational Communications and Technology (24th, Atlanta, GA, November 8-12, 2001). Volumes 1-2; see IR 021504.

Moradmand, N., Datta, A., \& Oakley, G. (2014). The design and implementation of an educational multimedia mathematics software: Using ADDIE to guide instructional system design. The Journal of Applied Instructional Design, 4(1), 37-49. Retrieved from

http://www.jaidpub.org/wp-content/uploads/2014/10/Moramand-Datta-Oakley.pdf.

Ormrod, J. E. (2000). Educational Psychology: Developing Learners. 3rd ed. Columbus, $\mathrm{OH}$ : Merrill Prentice Hall.

Peel, D. (2005). The significance of behavioural learning theory to the development of 
INTERNATIONAL JOURNAL OF ACADEMIC RESEARCH IN BUSINESS AND SOCIAL SCIENCES

effective coaching practice. International Journal of Evidence Based Coaching and Mentoring, 3(1), 18-28. Retrieved from http://ijebcm.brookes.ac.uk/documents/vol03issue1-paper-02.pdf.

Pearson, F. S., Lipton, D. S., Cleland, C. M., \& Dorline, S. Y. (2002). The effects of behavioral/cognitive-behavioral programs on recidivism. Crime \& Delinquency, 48(3), 476- 496. Retrieved from

http://www.d.umn.edu/ jmaahs/MA\%20Theory\%20Articles/meta\%20analysis\%20cog\%20 beh.pdf.

Sink, D. L. (2014). Chapter 11: Design Models and Learning Theories for Adults, pp. 181199 , Instructional design models and learning theories, American Society for Training \& Development (ASTD). Retrieved from http://dsink.com/downloads/10SinkASTDhandbook.pdf.

Vanasupa, L., Stolk, J., and Herter, R. J. (2009). "the four-domain development diagram: A guide for holistic design of effective learning experiences for the twenty-first century engineer." Journal of Engineering Education, 98 (1), 67-81. 